\title{
Evaluation of nociception comparing analgesia protocols in cats submitted to elective ovariohisterectomy
}

Avaliação da nocicepção comparando protocolos de analgesia em gatas submetidas à ovariohisterectomia eletiva

Evaluación de la nocicepción mediante la comparación de los protocolos de analgesia en gatos sometidos a histerectomía ovárica electiva

Mariza Fordellone Rosa Cruz ORCID: https://orcid.org/0000-0003-0993-315X Northern Paraná State University, Brazil

E-mail: mfordellone@uenp.edu.br

Thais Aparecida Wenceslau ORCID: https://orcid.org/0000-0001-7036-0181

Hospipet Veterinary Hospital, Brazil

E-mail: thaisapwenceslau@gmail.com

Carolina Miranda da Silva

ORCID: https://orcid.org/0000-0001-7678-0734

Northern Paraná State University, Brazil

E-mail: carolinamirandas1611@gmail.com

Dafne Fessel Zanardo

ORCID: https://orcid.org/0000-0002-0763-3893

Northern Paraná State University, Brazil

E-mail: dafnefez@gmail.com

Catarine Del Massa Martins

ORCID: https://orcid.org/0000-0003-1898-4311

Veterinary Clinic São Francisco de Assis, Brazil

E-mail: catarinedelmassa@gmail.com

Raquel Estefania Stringheta de Souza

ORCID: https://orcid.org/0000-0001-8560-8629

Northern Paraná State University, Brazil

E-mail: raquel_stringheta@yahoo.com.br

Nelly Braga Silva

ORCID: https://orcid.org/0000-0001-5794-3550

Northern Paraná State University, Brazil

E-mail: nellybragasilva@ hotmail.com

Natanne Terumy Miasaki

ORCID: https://orcid.org/0000-0002-2769-0924

Paulista State University Julio de Mesquita Filho, Brazil

E-mail: natannemiasaki@hotmail.com

Thalissa Fernanda Ciboldi

ORCID: https://orcid.org/0000-0002-7159-4761 Ingá University Center, Brazil

E-mail: thalissaciboldi@gmail.com

Fernanda Mayumi Massukado

ORCID: https://orcid.org/0000-0001-7366-8894

Northern Paraná State University, Brazil

E-mail: mayuminanda@gmail.com

Diego Resende Rodrigues

ORCID: https://orcid.org/0000-0002-9495-8943

Northern Paraná State University, Brazil

E-mail: diegopardal@uenp.edu.br 


\author{
Aline Villas Bôas Manoel Salvador \\ ORCID: https://orcid.org/0000-0001-8650-4792 \\ Veterinary Clinic Auqmia, Brazil \\ E-mail: alinevillasboas@ hotmail.com \\ Giovana Garcia \\ ORCID: https://orcid.org/0000-0002-9775-3775 \\ Northern Paraná State University, Brazil \\ E-mail: giovana-garcia@outlook.com \\ Ana Paula Millet Evangelista dos Santos \\ ORCID: https://orcid.org/0000-0003-0907-1203 \\ Northern Paraná State University, Brazil \\ E-mail: apmillet@uenp.edu.br
}

\begin{abstract}
Felines have a high potential to produce numerous progenies and the most indicated birth control is the ovariohysterectomy surgical procedure. The procedure causes a postoperative pain process, so an effective protocol is needed to assess pain and control it. The study was conducted with 40 females, which were divided into three distinct groups that were given different analgesic protocols, consisting of dipyrone sodium isolated, dipyrone sodium associated with meloxicam and dipyrone sodium associated with tramadol hydrochloride. The objective of the research was to evaluate three analgesic protocols in order to verify the most effective and affordable one. It was observed that the three protocols are viable and effective, however, dipyrone associated with meloxicam showed greater pain control.
\end{abstract}

Keywords: Melbourne pain scale; Sterilization; Population control; Felines.

\title{
Resumo
}

As gatas têm um alto potencial para produzir numerosas progênies e o controle de natalidade mais indicado é o procedimento cirúrgico de ovariohisterectomia. O procedimento causa um processo de dor pós-operatório, por isso é necessário um protocolo eficaz para avaliar a dor e controlá-la. O estudo foi realizado com 40 fêmeas, estas foram divididas em três grupos distintos que contavam com diferentes protocolos analgésicos, sendo compostos por dipirona sódica isolada, dipirona sódica associada ao meloxicam e dipirona sódica associada ao cloridrato de tramadol. O objetivo da pesquisa foi avaliar três protocolos analgésicos, a fim de verificar o mais eficaz e acessível. Foi observado que os três protocolos são viáveis e eficazes, entretanto, a dipirona associada ao meloxicam mostrou um maior controle da dor.

Palavras-chave: Escala de dor de Melbourne; Esterilização; Controle populacional; Felinos.

\section{Resumen}

Las gatas tienen un alto potencial para producir numerosas crías y el control de la natalidad más adecuado es el procedimiento quirúrgico de la ovariohisterectomía. El procedimiento provoca un proceso de dolor postoperatorio, por lo que es necesario un protocolo eficaz para evaluar el dolor y controlarlo. El estudio se llevó a cabo con 40 hembras, que se dividieron en tres grupos distintos que tenían diferentes protocolos analgésicos, consistentes en dipirona sódica sola, dipirona sódica asociada a meloxicam y dipirona sódica asociada a clorhidrato de tramadol. El objetivo de la investigación era evaluar tres protocolos analgésicos para comprobar cuál era el más eficaz y asequible. Se observó que los tres protocolos son viables y efectivos, sin embargo, la dipirona asociada al meloxicam mostró un mayor control del dolor.

Palabras clave: Escala de dolor de Melbourne; Esterilización, Control de la población; Felinos.

\section{Introduction}

Felines are short-gestating multiparous animals, with great potential for producing numerous progeny that can reach sexual maturity after six months of age, according to the São Paulo State Department of Health. These factors associated with irresponsible pet guardians contribute to the uncontrolled population growth of dogs and cats. The World Health Organization states that isolated activities of collection and disposal of dogs and cats are not effective for population control. It is essential to act on the cause of the problem, that is, uncontrolled animal breeding and the lack of human responsibility for their care (WHO 1990).

Surgical sterilization is the most indicated method for natality control, since they are minimally invasive techniques, preferably from eight weeks of age, reports Vieira (2008). The technique prevents breeding, avoids the transmission of 
venereal diseases, zoonoses and other diseases, such as uterine infection and mammary tumor in females and prostate tumor in males. It also reduces aggressiveness and the habit of urinating around the house (Andrade et al. 2012). However, for Paula and Molento (2012), every sterilization procedure represents a potential impact on the animal's well-being, especially during the immediate post-intervention period. In conventional ovariohysterectomy (OHE), somatic and visceral pain occurs, and may be mild to moderate, according to Gaynor (2009).

In 1986, the International Association for the Study of Pain classified pain as an unpleasant sensory and/or emotional experience that is associated with actual or potential injuries. Every animal is capable of feeling pain, any stimulus that causes pain in humans will also cause pain in animals, because they are endowed with anatomical and physiological components responsible for feeling pain. It is up to the veterinarian to identify and reduce this discomfort in the animal (Fantoni \& Mastrocinque 2015; Silva 2018).

\subsection{Pain physiology}

According to Martins and Flôr (2015), the way each animal feels pain is subjective, because it is related to the pain threshold that that animal has, according to the painful stimulus to which it was exposed. In veterinary medicine it is complicated to know the threshold of pain, since the animal does not speak, so it is essential that the veterinarian knows the pathophysiology of pain, particularities of the species and if the procedure he will do will cause pain in the animal. To understand the events that are present in the pathophysiology of pain, it is necessary to understand the processes of: transduction, peripheral sensitization, transmission, perception and modulation of pain (Fantoni \& Mastrocinque 2012).

Transduction is when a physical or chemical stimulus is transformed into an action potential, the action potential will leave the peripheral nerve fibers and will be transfered to the central nervous system (CNS), the transduction will give rise to the sensory-pain phenomenon. The stimulus will travel from the primary afferent fibers to the spinal cord and will be projected to the cortex, which is responsible for the conscious perception of pain (Fantoni \& Mastrocinque 2012; Alves et al. 2017). Also according to Fantoni and Mastrocinque (2012), "the inflammatory response that occurs following tissue injury is accompanied by the release of a "soup of algogenic substances", which, acting synergistically, alter the sensitivity of the nociceptors".

The transmission begins with the afferent nerve fibers, which carry the impulse to the grey substance of the dorsal horn in the spinal cord. The spinal nerves conduct the transmission in the trunk and limbs, in the viscera it occurs by the sympathetic, parasympathetic and splanchnic nerves, and finally in the head region, it occurs by the trigeminal nerve (Aleixo et al. 2016).

Several sites of the brain are responsible for the integration, processing and perception of pain information, the reticular activating system (RAS), participates in autonomic, motor and endocrine responses to pain. In the primary sensory cortex occurs the discrimination and localization of stimulus intensity, it modulates cognitive and affective aspects of the painful sensation (Fantoni \& Mastrocinque 2012).

Felines seem to be less likely to present behaviors suggestive of pain when compared to dogs in identical circumstances. This fact may contribute to undertreatment of pain (Otero 2005; Teixeira 2005). The cat has both physiological and behavioral characteristics that are important in pain assessment. However, physiological changes, e.g. heart and respiratory rate, pupillary size and neuroendocrine assays (cortisol, glucose, beta-endocrine etc.) are poorly correlated with acute pain in this species, in addition, anxiety, stress and fear affect these variables, especially in the hospital setting, according to Cambridge et al. (2000); Höglund et al. (2017).

Therefore, pain assessment is mainly performed through subjective behavioral changes, which can often be subtle in felines, an example is the response to palpation (Monteiro \& Steagall, 2018). Key behavioral indicators of abdominal pain in 
cats have been identified, which include abnormal postures (Waran et al. 2007). Another factor noted by Brondani et al. (2013) in painful cases is decreased appetite.

It can be extremely difficult to assess the degree of pain experienced by animals and their ability to deal with pain (Mathews 2000). In addition to understanding the pathophysiology of pain, it is necessary to know how to identify and assess pain in animals, for Martins and Flôr (2015), the methods responsible for this involve physiological, neuroendocrine and behavioral parameters.

To assist the veterinarian, the scales for identification of pain in animals were created and the University of Melbourne Pain Scale (UMPS) is one of them, it is divided into six categories, based on physiological responses (heart rate, respiratory rate, rectal temperature, salivation and dilated pupil) and specific behavioral (response to palpation at the surgical site, activity, vocalization, posture, mental status), being assigned a score from zero to three, being zero for the animal that did not change its behavior or vital parameter, and a score of three for the animal that changed its behavior or vital parameter, indicating pain and/or discomfort (Pohl et al. 2011).

The evaluation of multiple factors increases its sensitivity and specificity. However, it may not be sensitive enough to detect small changes in behavior (Ferreira, Braccini \& Franklin, 2014). UMPS also requires the observer to know the animal's normal mental state prior to surgery and anesthesia (Hansen 2003; Hellyer 2005). Other scales are UNESP Botucatu Multidimensional Scale, Glasgow Composite Scale, Visual Analog Scale, Numerical Rating Scale, and the University of Colorado Pain Scale.

It is essential that friendly handling techniques are done and that the location is calm, clean and warm, as the environment can help ameliorate the aversive aspects of hospitalization and pain (Rodan et al. 2011). Individual response to analgesic administration, individual behavior, age and concomitant illness should be considered in the acute pain assessment process (Monteiro \& Steagall 2018). Information about the cats personality is extremely relevant and can be taken into consideration during the assessment.

\subsection{Applied pharmacology}

The most frequently used classes of drugs for pain control are those with analgesic potential, such as nonsteroidal anti-inflammatory drugs (NSAIDs), opioids and others (Fantoni et al. 2002; Waran et al. 2010).

NSAIDs are among the most used drugs in Veterinary Medicine (MacAllister, 1994); they act by inhibiting cyclooxygenase-1 (COX-1), which is involved in the inflammatory process and in central and peripheral pain sensitization (Landoni 2005; Bassanezi; Oliveira Filho 2006 apud Castro 2011), resulting in analgesic, anti-inflammatory, and antipyretic action and can be used in both acute and chronic pain (Budsberd 2008; Teixeira 2010), but according to Pozzobon (2010), most produce side effects, such as gastrointestinal ulcers, kidney and liver damage, by inhibiting COX-1. Selective cyclooxygenase-2 (COX-2) inhibitors were introduced to the market and meloxicam was one of the first (Pozzobon 2010). Meloxicam is considered an enolic acid-derived NSAID (Panara et al. 1999) and according to Curry et al. (2005), it also has analgesic, antipyretic and anti-inflammatory properties.

Sodium dipyrone is a water-soluble pyrazolone derivative used as an analgesic, antipyretic and antispasmodic (Levy et al. 1995). According to Abbate et al. (1990), there is a central and peripheral action. The peripheral component is exerted by the inhibition of cyclooxygenase ( $\mathrm{COX}$ ), inhibiting the formation of prostacyclins, prostaglandins and thromboxane, which prevents the sensitization of nociceptors. Other studies have described dipyrone as being able to inhibit an isoenzyme of COX type 3, present mainly in the cerebral cortex, a central mechanism by which the drug would exert its analgesic and antipyretic action (Chandrasekharan et al. 2002). 
Tramadol hydrochloride is in the class of centrally acting analgesics, which inhibits the reuptake of serotonin and norepinephrine, thus acting as an $\alpha$-agonist. It also has moderate affinity for the $\mu$-opioid receptor (Lee et al. 1993; Raffa et al. 1993). Non-opioid mechanisms can potentiate analgesia without respiratory and cardiac depression (Vickers et al. 1992).

According to Luna (2008), the advancement of science and animal welfare has increased the critical sense of the need for pain prevention and treatment in animals. Then, due to its importance, pain and its control are subjects that are being increasingly studied (Tranquilli et al. 2013).

\section{Methodology}

The study was developed at the Veterinary School Hospital (HVE) of the Universidade Estadual do Norte do Paraná (UENP) and at the Veterinary Clinic Auqmia, in the city of Bandeirantes, Paraná, between 2016 and 2020. The activities began after approval by the Ethics Committee on Animal Use (ECAU) of UENP (Protocol: 03/2018).

There were 30 females of the feline specie selected from Non-Governmental Organizations (NGOs), so the clinical history was limited due to the lack of information on each animal. In the preoperative consultation, 12 hours solid and a four hours water fast was recommended preoperatively, an anamnesis of the animals was performed, as well as a general physical examination, mucosal staining, and capillary refill time, in addition to checking heart rate, respiratory rate, rectal temperature and degree of hydration. A pre-surgical hematological evaluation was also performed, which included: blood count, leukogram, and platelet count.

The cats were tranquilized with acepromazine hydrochloride 0.05 milligram per kilogram $(\mathrm{mg} / \mathrm{kg})$, followed by morphine $(0.2 \mathrm{mg} / \mathrm{kg})$ and cephalothin $(30 \mathrm{mg} / \mathrm{kg})$. After 15 minutes, the abdomen was trichotomized. Anesthetic induction was obtained by the application of propofol $(5 \mathrm{mg} / \mathrm{kg})$ intravenously.

The animals were sent to the operating room, where anesthesia was maintained with isofluorane in $100 \%$ oxygen, with assisted ventilation and a calibrated vaporizer. The animals received $0.9 \%$ sodium chloride intravenously (I.V.) until the moment of extubation. The animals were operated on by different surgeons, all proficient in the proposed technique.

Three postoperative analgesic protocols were elaborated, being them Protocol 1 (PG1), composed of dipyrone (25 $\mathrm{mg} / \mathrm{kg}$ SID) and containing 10 female cats, Protocol 2 (PG2), Protocol 2 (PG2), consisting of dipyrone (25 mg/kg SID) associated with tramadol (3 mg/kg TID) and containing 10 cats, and finally, Protocol 3 (PG3), consisting of dipyrone (25 $\mathrm{mg} / \mathrm{kg}$ SID) associated with meloxicam (0.1 mg/kg SID) and containing 10 cats, described in Table 1.

Table 1. Analgesic protocols for the feline specie.

\begin{tabular}{ccc}
\hline & Protocols & Dose \\
\hline Animals & Drug & $25 \mathrm{mg} / \mathrm{kg} / \mathrm{SID}^{*}$ \\
\hline $\mathbf{1 0}$ & Dipyrone sodium & $25 \mathrm{mg} / \mathrm{kg} / \mathrm{SID}^{*}$ \\
\multirow{2}{*}{$\mathbf{1 0}$} & Dipyrone sodium & $3 \mathrm{mg} / \mathrm{kg} / \mathrm{TID}^{* *}$ \\
& Tramadol hydrochloride & $25 \mathrm{mg} / \mathrm{kg} / \mathrm{SID}^{*}$ \\
\multirow{2}{*}{$\mathbf{1 0}$} & Dipyrone sodium & $0,1 \mathrm{mg} / \mathrm{kg} / \mathrm{SID}^{*}$ \\
\hline
\end{tabular}

* Semel in die (once a day)

**Ter in die (three times a day)

Source: Authors.

The surgical wounds were cleaned by the guardians with $0.9 \%$ sodium chloride solution and $1 \%$ chlorhexidine digliconate for seven days, and then the sutures were removed on the tenth day. 
To evaluate postoperative analgesia we used the University of Melbourne Pain Scale (UMPS) at T4, T24, T48 and T72 (hours post-procedure) (Table 2). In the evaluation by means of UMPS, in addition to the observation of the animal's behavior and palpation of the surgical incision, the values of heart rate (HR), respiratory rate (RR) and rectal temperature (RT) were measured, as well as the presence of salivation and pupil dilation, scored according to the categories evaluated in the scale previously described by Firth and Haldane (1999) cited by Oliveira (2016).

The analgesic rescue is performed when the sum of the scores reaches 9 or more, and is done with ketoprofen 2 $\mathrm{mg} / \mathrm{kg}$, intramuscular (I.M.), with previous administration of omeprazole orally with a concentration of $10 \mathrm{mg}$.

Table 2. University of Melbourne Pain Scale.

\begin{tabular}{|c|c|c|}
\hline Category & Descriptor & $\begin{array}{llll}\text { T4 } & \text { T24 } & \text { T48 } & \text { T72 }\end{array}$ \\
\hline \multicolumn{3}{|l|}{ 1. Physiological data } \\
\hline & Physiological data within the reference range & 0 \\
\hline & Dilated pupils & 2 \\
\hline \multicolumn{3}{|c|}{ Percent increase in heart rate compared to pre-procedure rate } \\
\hline & $>20 \%$ & 1 \\
\hline & $>50 \%$ & 2 \\
\hline \multirow{7}{*}{$1^{\mathrm{a}}$. } & $>100 \%$ & 3 \\
\hline & Percent increase in respiratory rate compared to pre-pr & ure rate \\
\hline & $>20 \%$ & 1 \\
\hline & $>50 \%$ & 2 \\
\hline & $>100 \%$ & 3 \\
\hline & Rectal temperature exceeds the reference range & 1 \\
\hline & Salivation & 2 \\
\hline \multirow{3}{*}{$\begin{array}{l}\text { 2. Response to } \\
\text { palpation }\end{array}$} & No change in pre-procedure behavior & 0 \\
\hline & Protects/reacts when touched & 2 \\
\hline & Protects/reacts before being touched & 3 \\
\hline \multirow[t]{6}{*}{ 3. Activity } & At rest: sleeping & 0 \\
\hline & At rest: semiconscious & 0 \\
\hline & At rest: awake & 1 \\
\hline & Eating & 0 \\
\hline & Restless (moving continuously, lifting and lowering) & 2 \\
\hline & Rolling, moving violently & 3 \\
\hline \multirow[t]{4}{*}{ 4. Mental state } & Submissive & 0 \\
\hline & Openly friendly & 1 \\
\hline & Cautious & 2 \\
\hline & Aggressive & 3 \\
\hline \multirow[t]{7}{*}{ 5. Posture } & Tries to protect the área affected (includes fetal position) & 2 \\
\hline & Lateral decubitus & 0 \\
\hline & Sternal decubitus & 1 \\
\hline & Sitting or stationary, head up & 1 \\
\hline & In station, head hanging down & 2 \\
\hline & Moving & 1 \\
\hline & Abnormal posture (kyphosis) & 2 \\
\hline \multirow[t]{4}{*}{ 6. Vocalization } & No vocalization & 0 \\
\hline & Vocalizes when touched & 2 \\
\hline & Intermittent vocalization & 2 \\
\hline & Continuous vocalization & 3 \\
\hline
\end{tabular}

Source: adapted from Firth and Haldene (1999). 


\section{Results and Discussion}

None of the means exceeded the score considered over moderate pain according to UMPS. However, in protocol PG1, four animals presented values over 9 at T24, as well as one animal at T48, requiring analgesic rescue. In relation to protocol G2, three animals presented high values at T24, so rescue was also performed. Finally, in protocol PG3, one animal presented a high score at T4 and two at T24, so rescue was performed. The protocols performed along with the scores for each animal are seen in the following tables.

Table 3. PG1 analgesic protocol consisting of dipyrone at a dose of $25 \mathrm{mg} / \mathrm{kg}$ SID at T4, T24, T48 and T72 postoperative times.

\begin{tabular}{ccccc} 
& T4 & T24 & T48 & T72 \\
\cline { 2 - 5 } Animal 1 & 4 & 3 & 3 & 2 \\
Animal 2 & 6 & 5 & 5 & 1 \\
Animal 3 & 2 & 7 & 1 & 2 \\
Animal 4 & 4 & 9 & 2 & 5 \\
Animal 5 & 6 & 11 & 2 & 2 \\
Animal 6 & 5 & 13 & 3 & 2 \\
Animal 7 & 4 & 12 & 9 & 7 \\
Animal 8 & 7 & 8 & 4 & 5 \\
Animal 9 & 4 & 3 & 1 & 0 \\
Animal 10 & 1 & 1 & 3 & 3 \\
\hline
\end{tabular}

Source: Authors.

Table 4. PG2 analgesic protocol consisting of dipyrone at a dose of $25 \mathrm{mg} / \mathrm{kg}$ SID associated with tramadol hydrochloride at a dose of $3 \mathrm{mg} / \mathrm{kg}$ TID at T4, T24, T48 and T72 postoperative times.

\begin{tabular}{ccccc} 
& T4 & T24 & T48 & T72 \\
\hline Animal 1 & 4 & 2 & 4 & 3 \\
Animal 2 & 6 & 5 & 5 & 3 \\
Animal 3 & 5 & 8 & 5 & 5 \\
Animal 4 & 7 & 11 & 2 & 2 \\
Animal 5 & 4 & 14 & 2 & 1 \\
Animal 6 & 5 & 17 & 1 & 1 \\
Animal 7 & 5 & 5 & 5 & 6 \\
Animal 8 & 3 & 5 & 5 & 5 \\
Animal 9 & 3 & 4 & 7 & 8 \\
Animal 10 & 5 & 1 & 3 & 2 \\
\hline
\end{tabular}

Source: Authors. 
Table 5. PG3 analgesic protocol consisting of dipyrone at a dose of $25 \mathrm{mg} / \mathrm{kg}$ SID associated with meloxicam at a dose of 0.1 $\mathrm{mg} / \mathrm{kg}$ SID at T4, T24, T48, and T72 postoperatively.

\begin{tabular}{ccccc} 
& T4 & T24 & T48 & T72 \\
\hline Animal 1 & 3 & 1 & 1 & 1 \\
Animal 2 & 6 & 3 & 1 & 1 \\
Animal 3 & 5 & 5 & 2 & 2 \\
Animal 4 & 6 & 7 & 4 & 5 \\
Animal 5 & 9 & 9 & 6 & 4 \\
Animal 6 & 3 & 11 & 1 & 1 \\
Animal 7 & 5 & 1 & 2 & 2 \\
Animal 8 & 7 & 1 & 3 & 1 \\
Animal 9 & 2 & 1 & 0 & 1 \\
Animal 10 & 3 & 4 & 0 & 2 \\
\hline
\end{tabular}

Source: Authors.

For statistical evaluation the Shapiro-Wilk test for normality was used, W being the statistical value, and the Anderson-Darling test for normality, A being the statistical value. Analysis of variance ANOVA and later Tukey's test were also performed; for one of the times, (T72), it was necessary to use the non-parametric Kruskal-Wallis test due to the fact that the treatment at this time did not meet the normality assumptions. The data were run in Rstudio software (Version 1.3.1056). For the normality test, it is understood that the p value needs to be greater than 0.05 ( $p>0.05$ ).

At T4, the value of W was 0.98206 , while in Tukey's Test, the p-value was 0.8773 . In the case of A value, it was 0.25237, while the $\mathrm{p}$ value was 0.7137 . Therefore, the data fit the normal distribution for both tests. Equal letters in the column Groups do not differ significantly from each other (ANOVA and Tukey's a posteriori test; $p<0.05$ ) (Table 6). Equal letters in the means column do not differ significantly from each other.

Table 6. Pain scale means by treatment analyzed after 4 hours (T4).

\begin{tabular}{ccccccc}
\hline Drug & $\begin{array}{c}\text { Mea } \\
\text { ns }\end{array}$ & $\begin{array}{c}\text { Standard } \\
\text { Error }\end{array}$ & $\begin{array}{c}\text { Degrees of } \\
\text { freedom }\end{array}$ & $\begin{array}{c}\text { Lower confidence } \\
\text { interval }\end{array}$ & $\begin{array}{c}\text { Upper confidence } \\
\text { interval }\end{array}$ & $\begin{array}{c}\text { Grou } \\
\text { ps }\end{array}$ \\
\hline $\begin{array}{c}\text { Dipyrone sodium } \\
\text { Dipyrone sodium + Tramadol }\end{array}$ & $4.3^{\mathrm{a}}$ & 0.568 & 27 & 2.85 & 5.75 & $\mathrm{~A}$ \\
$\begin{array}{c}\text { Hydrochloride } \\
4.7^{\mathrm{a}}\end{array}$ & 0.568 & 27 & 3.25 & 6.15 & $\mathrm{~B}$ \\
Dipyrone sodium + Meloxicam & $4.9^{\mathrm{a}}$ & 0.568 & 27 & 3.45 & 6.35 & $\mathrm{C}$ \\
\hline
\end{tabular}

Source: Authors.

At T24, the value of W was 0.94691, while in Tukey's Test, the p-value was 0.1396. In the case of the A value, it was 0.59524, while the p value was 0.1118 . Therefore, as in $\mathrm{T} 4$, the data fit the normal distribution for both tests. Equal letters in the column Groups do not differ significantly from each other (ANOVA and Tukey's a posteriori test; $p<0.05)($ Table 7). Equal letters in the means column do not differ significantly from each other. 
Table 7. Pain scale means by treatment analyzed after 24 hours (T24).

\begin{tabular}{ccccccc}
\hline Drug & $\begin{array}{c}\text { Mea } \\
\text { ns }\end{array}$ & $\begin{array}{c}\text { Standard } \\
\text { Error }\end{array}$ & $\begin{array}{c}\text { Degrees of } \\
\text { freedom }\end{array}$ & $\begin{array}{c}\text { Lower confidence } \\
\text { interval }\end{array}$ & $\begin{array}{c}\text { Upper confidence } \\
\text { interval }\end{array}$ & $\begin{array}{c}\text { Grou } \\
\text { ps }\end{array}$ \\
\hline Dipyrone sodium & $4.3^{\mathrm{a}}$ & 1.39 & 27 & 0.764 & 7.84 & $\mathrm{~A}$ \\
Dipyrone sodium + Tramadol & $7.2^{\mathrm{a}}$ & 1.39 & 27 & 3.664 & 10.74 & $\mathrm{~B}$ \\
$\begin{array}{c}\text { Hydrochloride } \\
\text { Dipyrone sodium + Meloxicam }\end{array}$ & $7.2^{\mathrm{a}}$ & 1.39 & 27 & 3.664 & 10.74 & $\mathrm{C}$ \\
\hline
\end{tabular}

Source: Authors.

At $\mathrm{T} 48$, the value of $\mathrm{W}$ was 0.93055 , while in Tukey's Test, the p-value was 0.05079. In the case of the A value, it was 0.5884 , while the $\mathrm{p}$ value was 0.1164 . Therefore, as in the previous cases, the data fit the normal distribution for both tests. Equal letters in the column Groups do not differ significantly from each other (ANOVA and Tukey's a posteriori test; $p<0.05$ ) (Table 8). Equal letters in the means column do not differ significantly from each other.

Table 8. Pain scale means by treatment analyzed after 48 hours (T48).

\begin{tabular}{ccccccc}
\hline Drug & $\begin{array}{c}\text { Mea } \\
\text { ns }\end{array}$ & $\begin{array}{c}\text { Standard } \\
\text { Error }\end{array}$ & $\begin{array}{c}\text { Degrees of } \\
\text { freedom }\end{array}$ & $\begin{array}{c}\text { Lower confidence } \\
\text { interval }\end{array}$ & $\begin{array}{c}\text { Upper confidence } \\
\text { interval }\end{array}$ & $\begin{array}{c}\text { Grou } \\
\text { ps }\end{array}$ \\
\hline $\begin{array}{c}\text { Dipyrone sodium } \\
\text { Dipyrone sodium + Tramadol }\end{array}$ & $2^{\mathrm{a}}$ & 0.647 & 27 & 0.354 & 3.65 & $\mathrm{~A}$ \\
Hydrochloride & $3.3^{\mathrm{a}}$ & 0.647 & 27 & 1.654 & 4.95 & $\mathrm{~B}$ \\
Dipyrone sodium + Meloxicam & $3.9^{\mathrm{a}}$ & 0.647 & 27 & 2.254 & 5.55 \\
$\mathrm{C}$
\end{tabular}

Source: Authors.

In T72, the value of $\mathrm{W}$ was 0.91838 , while in Tukey's Test, the p-value was 0.02435 . In the case of A value, it was 1.063, while the $\mathrm{p}$ value was 0.007303 . Therefore, in both tests it was found that $\mathrm{p}<0.05$, so the data does not fit the normal distribution. Equal letters in the column Groups do not differ significantly from each other (Kruskal-Wallis parametric test) (Table 9). Equal letters in the means column do not differ significantly from each other.

Table 9. Pain scale medians by treatment analyzed after 72 hours (T72).

\begin{tabular}{|c|c|c|c|c|c|c|}
\hline Drug & $\mathbf{N}$ & Medians & $\begin{array}{c}\text { Confidence } \\
\text { Level }\end{array}$ & $\begin{array}{c}\text { Lower } \\
\text { percentile }\end{array}$ & $\begin{array}{c}\text { Upper } \\
\text { percentile }\end{array}$ & Groups \\
\hline Dipyrone sodium & 10 & $1.5^{\mathrm{a}}$ & 0.95 & 1 & 3 & A \\
\hline Dipyrone sodium + Tramadol Hydrochloride & 10 & $2^{\mathrm{a}}$ & 0.95 & 1.5 & 5 & $\mathrm{~B}$ \\
\hline Dipyrone sodium + Meloxicam & 10 & $3^{\mathrm{a}}$ & 0.95 & 1.5 & 5.5 & $\mathrm{C}$ \\
\hline
\end{tabular}

Source: Authors.

The treatment of post-surgical pain is extremely important for ethical and humanitarian reasons and to prevent the occurrence of deleterious effects on the body, such as on the metabolic, neuroendocrine and immune systems resulting from pain (Desborough 2000; Mui, 2008). The selection of ovariohysterectomy was based on the fact that it is common in the surgical routine and for favoring the population control of stray animals. It should be noted that, although many studies recommend pain assessment in a control group (without analgesia), it did not occur in this study, justified by ethical and animal welfare reasons, since it is a surgery that promotes pain, according to Paulo (2014).

Dipyrone is an analgesic widely used for pain control and as an antipyretic, but there are few published studies on its efficacy and safety in animals, especially felines. In the case of meloxicam, Mathews (2000), points out that NSAIDs have a longer period of action when compared to opioids, and it is possible to mention tramadol hydrochloride. This fact can be observed when comparing PG2 with PG3, because the latter has considerably lower values. 
Coleman (2007) states that several studies show that cats receive less analgesia than dogs under the same condition. Smith et al. (1996), adds that this is due to the fact that it is hardly evaluated in this species because in the presence of pain, cats remain silent. Other factors are the limited choice of analgesics and the fear of side effects.

However, it is known that felines are the fastest growing pets in terms of population in Brazil (Brazil 2015), and there is also an increase in veterinary care for this species. Thus, it is extremely important to know about analgesia in order to provide well-being.

\section{Conclusions}

Due to the inability of verbal communication and recognition, pain assessment becomes a challenge, therefore, it is essential to know the ethology, environmental, physiological and behavioral variations of the species studied, besides considering the animal as a unique being. In the current study, there was no statistically significant difference because the sample number $(\mathrm{N})$ was low; therefore, it was concluded that increasing the number of animals in the study will lead to relevant differences between treatments. Even so, the association between dipyrone sodium and meloxicam showed the lowest mean and median, indicating more effective analgesia. In view of this, studies with meloxicam alone will be necessary for a possible comparison with dipyrone. However, due to the absence of significant difference, dipyrone becomes a viable option, especially for its low cost.

\section{References}

Abbate, R., Gori, A. M., Pinto, P., Attanasio, M., Paniccia, R., Coppo, M., Castellani, S., Giusti, B., Boddi, M. \& Neri Serneri, G. G. (1990). Cyclooxygenase and lipoxygenase metabolite synthesis by polymorphonuclear neutrophils: in vitro effect of dipyrone. Prostaglandins, Leukotrienes and Essential Fatty Acids, 41 (2) 89-93.

Aleixo, G. A. S., Tudury, E. A., Coelho, M. C. O. C., Andrade, L. S. S. \& Bessa, A. L. N. G. (2016). Tratamento da dor em pequenos animais: fisiopatologia e reconhecimento da dor (revisão de literatura: parte 1). Medicina Veterinária (UFRPE), 10 (1-4), 19-24.

Alves, J. E. O., Silveira, M. D., Vieira, E. M. P. \& Vidal, L. W. M. (2017). Mecanismo fisiopatológicos da nocicepção e bases das analgesias preparatórias em pequenos animais. Acta Biomédica Brasiliensia, 8 (1), 56-68.

Andrade, A. F. S., Buquera, L. E. C., Dantas, E. F., Oliveira M. K. \& Trajano, S. C. (2012). Controle populacional por meio de esterilização cirúrgica e posse responsável. Anais... Campina Grande: Universidade Federal da Paraíba.

Brondani, J. T., Mama, K. R., Luna, S. P. L., Wright, B. D., Niyom, S., Ambrosio, J., Vogel, P. R. \& Padovani, C. R. (2013). Validation of the English version of the UNESP-Botucatu multidimensional composite pain scale for assessing postoperative pain in cats. BMC Vet Res, 9 (143) 1-15.

Budsberd, S. (2008). Nonsteroidal Antiinflammatory Drugs. In: Gaynor, J. S.; Muir, W.W. Handbook of Veterinary Pain Management. Mosby.

Cambridge, A. J., Tobias, K. M., Newberry, R. C. \& Sarkar, D. K. (2000). Subjective and objective measurements of postoperative pain in cats. J Am Vet Med Assoc, 217 (5) 685-690.

Castro, A. G. (2011). Dor perioperatória em animais de companhia: fisiopatologia, avaliação e controle. Monografia (Especialização) - Universidade Federal de Minas Gerais, Belo Horizonte. Especialização em Residência em Medicina Veterinária.

Chandrasekharan, N. V., Dai, H., Roos, K. L. T., Evanson, N. K., Tomsik, J., Elton, T. S. \& Simmons, D. L. (2002). COX-3, a cyclooxygenase-1 variant inhibited by acetaminophen and other analgesic/antipyretic drugs: cloning, structure, and expression. Proceedings of the national academy of sciences, 99 (21) 1396-1393.

Curry, S., Cogar, S. M. \& Cook, J. L. (2005). Nonsteroidal antiinflammatory drugs: a review. J Am Anim Hosp Assoc, 41 (5) $298-309$.

Desborough, J.P. (2000). The stress response to trauma and surgery. British Journal of Anaesthesia, 85 (1) 109-17.

Fantoni, D. \& Mastrocinque, S. (2012). Fisiopatologia da dor aguda. In: Fantoni, D. Tratamento da dor clínica em pequenos animais. Elsevier.

Fantoni, D. T., Mastrocinque, S., Fantoni, D. T. \& Cottopassi, S. R. (2002). Fisiopatologia e controle da dor. In: D. T. Fantoni (Ed.), Anestesia em cães e gatos, Roca.

Fantoni, D. T. \& Mastrocinque, S. (2015). Fisiopatologia da dor. In: Jericó, M. M., Neto, J. P. A., Kogika M. M., Tratado de medicina interna de cães e gatos. Editora Guanabara Koogan.

Ferreira, L. F. L., Braccini, P. \& Franklin, N. (2014). Escala de dor em pequenos animais - revisão de literatura. PUBVET, 8 (1) 1-8. 
Firth, A. M. \& Haldane, S. L. (1999). Development of a scale to evaluate postoperative pain in dogs. Journal of the American Veterinary Medical Association, 214 (5) 651-659.

Flôr, P. B., Martins, T. L. \& Yazbek, K. V. B. (2012). Avaliação da dor. In: Fantoni, D. Tratamento da dor clínica em pequenos animais. Elsevier

Gaynor, J. S. \& Muir, W. W. (2009). Manual de Controle da Dor em Medicina Veterinária. MedVet, 2. Ed.

Hansen, B. D. (2003). Assessment of pain in dogs: veterinary clinical studies. ILAR Journal, 44 (3) 197-205.

Höglund, O. V., Dyall, B., Gräsman, V., Edner, A., Olsson, U. \& Höglund, K. (2018). Effect of non-steroidal anti-inflammatory drugs on postoperative respiratory and heart rate in cats subjected to ovariohysterectomy. J Feline Med Surg. 20 (10) 980-984.

Lee, C. R., McTavish, D. \& Sorkin, E. M. (1993). Tramadol: A preliminary review of its pharmacodynamic and pharmacokinetic properties, and therapeutic potential in acute and chronic pain states. Drugs, (2) 313-340.

Levy, M., Zylber-Katz, E. \& Rosenkranz, B. (1995). Clinical pharmacokinetics of dipyrone and its metabolites. Clin. Pharmac., 28 (3) 216-233

Luna, S. P. L. (2008). Dor, senciência e bem-estar em animais. Ciência Veterinária nos Trópicos, 11 (1) 17-21

MacAllister, C. G., Morgan, S. J. \& Borne, A. (1994). Comparison of adverse effects of phenylbutazone, flunixin meglumine, and ketoprofen in horses. Journal of the American Veterinary Medical Association, 202 (1) 71-77.

Mathews, K. A. (2000). Pain assessment and general approach to management. Veterinary Clinics of North America: Small Animal Practice, 30 (4) $729-755$.

Monteiro, P. B. \& Steagall, P. V. (2018). Acute pain in cats: recente advances in clinical assessment. Journal of Feline Medicine and Surgery, 21 (1) 25-34.

Muir, W.W. (2008). Pain and Stress. In: J.S. Gaynor \& W.W. Muir (Eds.), Handbook of Veterinary Pain Management (2nd ed.) 42-56. Missouri: Mosby An Affiliate of Elsevier.

Otero, P. E. (2005). Manejo da dor em medicina veterinária. In: Otero, P. E. Dor: avaliação e tratamento em pequenos animais. Interbook.

Panara, M. R., Renda, G., Sciulli, M. G., Santini, G., Giamberardino, M. Di., Rotonto, M., T., Tacconelli, S., Seta, F., Patrono, C. \& Patrignani, P. (1999). Dose-Dependent Inhibition of Platelet Cyclooxygenase-1 and Monocyte Cyclooxygenase-2 by Meloxicam in Healthy Subjects. Journal of Pharmacology and Experimental Therapeutics, 290 (1) 276-280.

Paula, P. M. C. \& Molento, C. F. M. (2012). Avaliação da dor pós-intervenção em três métodos de esterilização de cães machos. Brazilian Journal of Veterinary Research and Animal Science, 49 (4) 255-261.

Paulo, N. M. A. (2014). Avaliação da dor na cirurgia e pós-operatório em cadelas submetidas a ovariohisterectomia eletiva. Dissertação (Mestrado) Universidade Lusófona de Humanidades e Tecnologias. Área: Medicina Veterinária.

Pohl, V. H., Carregaro, A. B., Lopes, C., Garlet, C. \& Marques, J. S. (2011). Correlação entre as escalas visual analógica de Melbourne e filamentos de Von Frey na avaliação da dor pós-operatória em cadelas submetidas a ovariossalpingohisterectomia. Ciência Rural, Santa maria, 41 (1), 154-159.

Pozzobon, R. (2010). Avaliação farmacocinética, hematológica e espermática de pôneis tratados com meloxicam. Tese (Doutorado) - Universidade Federal de Santa Maria. Área: Fisiopatologia da Reprodução.

Raffa, R. B., Friederich, E., Reimann, W., Shank, R. P., Codd, E. E., Vaught, J. L., Jacoby, H. I. \& Selve, N. (1993). Complementary and synergistic antinociceptive interaction between the enantiomers of tramadol. Journal of pharmacology and experimental therapeutics, 267 (1) 331-340.

Rodan, I., Sundahl, E., Carney, H., Gagnon, A. C., Heath, S., Landsberg, G., Seksel, K. \&Yin, S. (2011). AAFP and ISFM Feline-Friendly Handling Guidelines. J Feline Med Surg, 13 (5) 364-375.

Secretaria de Estado da Saúde de São Paulo. (2006). Programa de Controle de Populações de Cães e Gatos do Estado de São Paulo. São Paulo, Boletim Epidemiológico Paulista.

Silva, F. G. (2018). Estudo comparativo do uso de escalas descritivas e semi-objectivas na avaliação da dor animal. Dissertação (Mestrado) - Escola Superior Agrária de Viseu. Área: Medicina Veterinária.

Teixeira, F. M. (2010). Avaliação comparativa do efeito de fármacos anti-inflamatórios com acupuntura no modelo de dor pós-incisional em ratos. Dissertação (Mestrado) - Universidade Federal Rural do Rio de Janeiro. Área: Medicina Veterinária.

Teixeira, M. W. (2005). Dor em pequenos animais. Revista CFMV. Conselho Federal de Medicina Veterinária, 34 (11) 31-41.

Tranquilli, W. J., Thurmon, J. C. \& Grimm, K. A. (2013). Lumb and Jones' veterinary anesthesia and analgesia. John Wiley \& Sons.

Vickers, M. D, O’Flaherty, D., Szekely, S. M., Read, M. \& Yoshizumi, J. (1992). Tramadol: pain relief by na opioid without depression of respiration. Anesthesia, 47 291-296.

Vieira, A. M. L. (2008). Controle populacional de cães e gatos. Aspectos Técnicos e operacionais. Ciência Veterinária nos Trópicos, 11 (1) $102-105$.

Waran, N., Williams, V. M., Clarke, N. \& Bridge, I. S. (2010). Recognition of pain and use of analgesia in horses by veterinarians in New Zealand. New Zealand Veterinary Journal, 58 (6) 274-280.

WHO. WSPA. (1990). World Health Organization. World Society for the Protection of Animals. Guidelines for dog population management. 